\title{
Comparison of Phlebitis Produced by Cephapirin and Cephalothin
}

\author{
ALAN S. CROSS* AND EDMUND C. TRAMONT \\ Division of Infectious Diseases, Department of Medicine, Walter Reed Army Medical Center, and Department \\ of Bacterial Diseases, Walter Reed Army Institute of Research, Washington, D. C. 20012*
}

Received for publication 14 November 1975

In a single-blinded study involving 120 patients neither the incidence nor severity of phlebitis observed with cephapirin and cephalothin was significantly different.

Recently there has become available a number of new semisynthetic cephalosporin antibiotics for intramuscular and intravenous use. Since to date no single preparation is more effective than another, an agent would be a useful addition to hospital formularies only if intravenous injections of the drug were better tolerated.

Phlebitis is a common and troublesome side effect of intravenous cephalosporin therapy. There have been conflicting reports as to whether the use of a newer cephalosporin antibiotic preparation, cephapirin, results in a lower incidence of phlebitis (1-5). To determine which situation prevailed in our hospital, the incidence and severity of phlebitis was determined and compared to cephalothin in a singleblind fashion.

Patients receiving cephapirin or cephalothin were identified by the pharmacy. These patients, male and female adults, were then examined by one or both authors. The drug preparation that the patient was receiving was not known to the authors until after the patient was taken off therapy.

The dose of the antimicrobial was not controlled since we wished to study the drugs as they would normally be used in the hospital by ward physicians. The dose of cephalothin ranged from $500 \mathrm{mg}$ every $6 \mathrm{~h}$ to $2 \mathrm{~g}$ every $4 \mathrm{~h}$, but most patients received $1 \mathrm{~g}$ every 6 to $8 \mathrm{~h}$. The dose of cephapirin ranged from $667 \mathrm{mg}$ every $12 \mathrm{~h}$ to $3.33 \mathrm{~g}$ every $6 \mathrm{~h}$, but most received $1 \mathrm{~g}$ every $8 \mathrm{~h}$. In over $90 \%$ of the cases, a polyethylene long-dwell catheter was used and the catheter was placed in an arm or hand vein. These catheters stayed in place from 24 to $216 \mathrm{~h}$; however, the great preponderance had the catheter in the same site less than 4 days (Table 1 and 2).

Antibiotics were administered within a halfhour and the only medications traversing the same infusion site were gentamicin, carbenicil- lin, and potassium chloride (the latter was always less than $20 \mathrm{meq}$ and given over long periods of time). The distribution of long-dwell catheters, duration of catheterization, other infusions, ages, and sex of patients were similar for both groups.

The degree of phlebitis was recorded as follows: 0 , no erythema or tenderness; $1+$, erythema and/or mild tenderness extending along the vein less than $2.5 \mathrm{~cm}$ above the infusion site; $2+$, erythema and/or mild tenderness extending along the vein more than $2.5 \mathrm{~cm}$ above the infusion site; $3+$, erythema and/or severe

TABLE 1. Incidence of phlebitis with cephapirin

\begin{tabular}{|c|c|c|c|c|c|c|}
\hline \multirow{2}{*}{$\begin{array}{l}\text { Total days } \\
\text { catheter } \\
\text { in place }\end{array}$} & \multicolumn{4}{|c|}{ Degree of phlebitis } & \multirow{2}{*}{$\begin{array}{l}\text { Total no. of } \\
\text { reaction/no. } \\
\text { of patients }\end{array}$} & \multirow{2}{*}{$\begin{array}{c}2+\text { and } 3+ \\
\text { phlebitis/ } \\
\text { no. of pa- } \\
\text { tients }\end{array}$} \\
\hline & 0 & $\begin{array}{c}1+ \\
\text { (Pain) }\end{array}$ & $2+$ & $3+$ & & \\
\hline $\begin{array}{l}1 \\
2\end{array}$ & $\begin{array}{r}15 \\
4\end{array}$ & $\begin{array}{l}8 \\
5\end{array}$ & $\begin{array}{l}0 \\
1\end{array}$ & $\begin{array}{l}0 \\
0\end{array}$ & $\begin{array}{l}8 / 23 \\
6 / 10\end{array}$ & $\begin{array}{l}0 / 23 \\
1 / 10\end{array}$ \\
\hline 3 & 3 & 0 & 1 & 1 & $2 /$ & $2 / 5$ \\
\hline $\begin{array}{r}4 \\
>4\end{array}$ & $\mathbf{0}$ & $\begin{array}{l}2 \\
1\end{array}$ & 1 & 1 & $\begin{array}{l}4 / 4 \\
1 / 1\end{array}$ & $\begin{array}{l}2 / 4 \\
0 / 1\end{array}$ \\
\hline Total & 22 & 16 & 3 & 2 & $21 / 43(49 \%)^{a}$ & $5 / 43(12 \%)^{\phi}$ \\
\hline
\end{tabular}

a Incidence of reactions with cephapirin not statistically different from that observed with cephalothin by chi-square test $(P>0.5)$.

- Incidence of severe reactions with cephapirin not statistically different from that observed with cephalothin $(P>$ 0.12).

TABLE 2. Incidence of phlebitis with cephalothin

\begin{tabular}{|c|c|c|c|c|c|c|}
\hline \multirow{2}{*}{$\begin{array}{l}\text { Total days } \\
\text { catheter } \\
\text { in place }\end{array}$} & \multicolumn{4}{|c|}{ Degree of phlebitis } & \multirow{2}{*}{$\begin{array}{l}\text { Total no. of } \\
\text { reactions/ } \\
\text { no. of pa- } \\
\text { tients }\end{array}$} & \multirow{2}{*}{$\begin{array}{c}2+\text { and } 3+ \\
\text { phlebitis/ } \\
\text { no. of pa- } \\
\text { tients }\end{array}$} \\
\hline & 0 & $\begin{array}{c}1+ \\
\text { (Pain) }\end{array}$ & $2+$ & $3+$ & & \\
\hline 1 & 16 & 6 & 3 & 2 & $11 / 27$ & $5 / 27$ \\
\hline 2 & 12 & 7 & 0 & 5 & $12 / 24$ & $5 / 24$ \\
\hline 3 & 4 & 3 & 3 & 3 & $9 / 13$ & $6 / 13$ \\
\hline 4 & 3 & 6 & 1 & 1 & $8 / 11$ & $2 / 11$ \\
\hline$>4$ & & 2 & & & $2 / 2$ & $0 / 2$ \\
\hline Total & 35 & 24 & 7 & 11 & 42/77 (55\%) & $18 / 77(23 \%)$ \\
\hline
\end{tabular}


TABLE 3. Comparison of patients taking cephapirin

\begin{tabular}{|c|c|c|c|c|c|c|c|c|c|c|c|c|c|}
\hline \multirow[b]{2}{*}{ Reference } & \multirow[b]{2}{*}{$\begin{array}{c}\text { Drug Dosage (in } \\
\text { grams) }\end{array}$} & \multirow[b]{2}{*}{$\begin{array}{c}\text { Method } \\
\text { of infu- } \\
\text { sion }\end{array}$} & \multirow[b]{2}{*}{ Catheter } & \multicolumn{5}{|c|}{ Cephapirin } & \multicolumn{5}{|c|}{ Cephalothin } \\
\hline & & & & $\begin{array}{c}\text { Total } \\
\text { no. of } \\
\text { pa- } \\
\text { tients }\end{array}$ & $\begin{array}{c}\text { Total } \\
\text { cases } \\
\text { of } \\
\text { phle- } \\
\text { bitis }\end{array}$ & $\begin{array}{c}1+ \\
\text { Mild }\end{array}$ & $\begin{array}{c}2+ \\
\text { Mod- } \\
\text { erate }\end{array}$ & $\begin{array}{c}3+ \\
\text { Se- } \\
\text { vere }\end{array}$ & $\begin{array}{c}\text { Total } \\
\text { no. of } \\
\text { pa- } \\
\text { tients }\end{array}$ & $\begin{array}{c}\text { Total } \\
\text { cases } \\
\text { of } \\
\text { phle- } \\
\text { bitis }\end{array}$ & $\begin{array}{c}1+ \\
\text { Mild }\end{array}$ & $\begin{array}{l}2+ \\
\text { Mod- } \\
\text { erate }\end{array}$ & $\begin{array}{l}3+ \\
\text { Se- } \\
\text { vere }\end{array}$ \\
\hline $\begin{array}{l}1^{a, d} \\
5^{d}\end{array}$ & $\begin{array}{l}1-2 \text { every } 6 \mathrm{~h} \\
0.5-1.0 \\
0.5-1.0\end{array}$ & $\begin{array}{l}\mathbf{R} \\
\mathbf{R} \\
\mathbf{C}\end{array}$ & $\begin{array}{l}\text { Scalp vein } \\
\text { NS }\end{array}$ & $\begin{array}{r}4 \\
22\end{array}$ & $\begin{array}{l}\mathbf{0} \\
\mathbf{0}\end{array}$ & $\begin{array}{l}\mathbf{0} \\
\mathbf{0}\end{array}$ & $\begin{array}{l}0 \\
0\end{array}$ & $\begin{array}{l}0 \\
0\end{array}$ & 4 & 4 & NS & NS & NS \\
\hline $4^{a, c}$ & $\begin{array}{l}0.5 \text { every } 6 \mathrm{~h} \text { for } 24 \mathrm{~h} \\
\text { then } 1.0 \text { every } 6 \mathrm{~h} \\
\text { for } 96 \mathrm{~h}\end{array}$ & $\mathbf{C}$ & $\begin{array}{l}\text { 21-gauge } \\
\text { needle }\end{array}$ & 10 & 2 & 2 & $\mathbf{0}$ & 0 & 10 & 8 & 5 & 2 & 1 \\
\hline $3^{b, d}$ & 3.0 every $6 \mathrm{~h}$ & $\begin{array}{c}\text { Over } \\
1^{\circ}\end{array}$ & Scalp vein ${ }^{f}$ & 120 & 66 & 55 & 9 & 2 & 94 & 52 & 33 & 16 & 3 \\
\hline $2^{b, c}$ & 2.0 every $6 h$ for $48 h$ & $\mathbf{R}$ & Scalp vein ${ }^{e}$ & 9 & 9 & 3 & 6 & 0 & 11 & 10 & 6 & 3 & 1 \\
\hline $\begin{array}{l}\text { Present } \\
\text { study }{ }^{a, c}\end{array}$ & $\begin{array}{c}\text { Cephalothin } 1.0 \text { every } \\
6 \mathrm{~h}(0.5 \text { every } 6 \mathrm{~h}-2 \\
\text { every } 4 \mathrm{~h}) \\
\text { Cephapirin } 1.0 \text { every } \\
8 \mathrm{~h}(0.667 \text { every } 12 \\
\mathrm{h}-3.33 \text { every } 6 \mathrm{~h})\end{array}$ & $\mathbf{R}$ & Long dwellf & 43 & 21 & 16 & 3 & 2 & 77 & 42 & 24 & 7 & 11 \\
\hline
\end{tabular}

a Single-blind study.

- Double-blind study.

c Adult patients.

d Sex of patient not stated.

e No other infusions.

Infusion with carbenicillin, gentamicin, and potassium chloride; Lane et al. (4) also infused platelets, erythrocytes and leukocytes.

- R, Rapid infusion; C, continuous; NS, not stated.

tenderness extending along the vein greater than $2.5 \mathrm{~cm}$.

The chi-square test was used for statistical analysis.

Seventy-seven patients received cephalothin and 43 patients received cephapirin (Table 1 and 2). There was no significant difference in the incidence of reactions $(P>0.5)$. Both groups of patients had a high overall rate of phlebitis associated with cephalosporin use, 49\% for cephapirin, and $55 \%$ for cephalothin.

Cephalothin therapy did, however, result in a greater severity of phlebitis but this was not statistically significant $(P>0.12)$. Of those receiving cephalothin, $23 \%$ had $2+$ or $3+$ reactions as opposed to $12 \%$ receiving cephapirin. The likelihood of reactions to both drugs increased with increasing duration of catheterization.

The number of infusions lasting 2 days or less was similar for both groups. Ten of 51 patients treated with cephalothin for 2 days or less had $2+$ or $3+$ phlebitis, whereas only 1 of 33 patients treated with cephapirin for 2 days or less had phlebitis with this degree of severity. This is a highly significant difference $(P<0.005)$.

Cephapirin sodium is a cephalosporin for parenteral use that has a spectrum and an activity equivalent to those for cephalothin (1). The dosage, blood levels, minimal inhibitory concen- tration and excretion patterns are also similar (5). However, there are conflicting data on the incidence of phlebitis with cephapirin (Table 3). Quintiliani et al. (5) gave cephapirin intravenously to 22 patients with a wide spectrum of infectious diseases and found no phlebitis. In a single-blinded study of 10 healthy subjects, cephalothin caused phlebitis more frequently and more severely than did cephapirin (4). Inagaki and Bodey (3) reported that while the overall incidence of phlebitis was similar for both drugs, severe phlebitis occurred twice as often in the cephalothin-treated group.

On the other hand, a double-blind study of 20 patients reported no difference in either the incidence or the degree of phlebitis with the two cephalosporins (5).

Our study suggests that the overall incidence and severity of phlebitis is similar in both groups; however, cephapirin gave significantly less severe reactions during the first $48 \mathrm{~h}$ of infusion.

We gratefully acknowledge the secretarial assistance of Lorraine Taylor and Doris Fisher in the preparation of this manuscript.

\section{LITERATURE CITED}

1. Bran, J. L., M. B. Levison, and D. Kaye. 1972. Clinical and in vitro evaluation of cephapirin, a new cephalosporin antibiotic. Antimicrob. Agents Chemother. 1:35-40. 
2. Carrizosa, J., M. E. Levison, and D. Kaye. 1973. Doubleblind controlled comparison of phlebitis produced by cephapirin and cephalothin. Antimicrob. Agents Chemother. 3:306-307.

3. Inagaki, J., and G. Bodey. 1973. Phlebitis association with cephalosporins: cephapirin versus cephalothin Curr. Ther. Res. Clin. Exp. 15:37-40.

4. Lane, A. Z., J. G. Taggart, and R. L. Iles. 1972. Relative incidence of phlebitis caused by intravenous infusion of cephapirin and cephalothin. Antimicrob. Agents Chemother. 2:234-235.

5. Quintiliani, R. A., A. Lentnik, M. Compos, and H. Dimeola. 1972. Efficacy and safety evaluation of cephapirin in hospitalized patients. Clin. Med. 79:1720. 